of 14 books, he brings practical

knowledge to both courses.

Simon stated that, though he received generous offers from universities and institutes throughout the country, he chose Southern Illinois because of its racial diversity and because it has the most first-generation college students in the Illinois state university system. This semester alone, he teaches over 100 of those students.

\section{A Learned Government: PhDs in Office}

Americans often assume the study of law is the path to political office. But men and women of letters also hold the reins of government. Seventeen Ph.D.s took oaths of office as Members of Congress in January, while three remain in the Senate.

Of the 20 Ph.D.s presently serving in Congress, five received their training in political science, making it the top discipline among Ph.D.s in the national legislature. Political scientists include Representative Steve Horn (R-CA), former Congressional Fellow and member of the CFP Advisory Board, Representative David Price (D-NC), also an Advisory Board member, and Representative Tim Roemer (D-IL). Senators Daniel Patrick Moynihan (D-NY) and Paul Wellstone (D-MN) represent the discipline in the Senate.

Second to political science is economics with three Ph.D.s. House economists are Representatives Tom Lantos (D-CA) and Dick Armey (RTX), while Phil Gramm (R-TX) is in the Senate.

History and religion each claim two legislators in their disciplines: in history, House Majority Leader Newt Gingrich (R-GA) and Representative Philip Crane (R-IL) and, in religion, Representative Danny Davis (D-IL) and the newly-elected Walter Capps (D-CA), winner of a hotly contested race against former Republican Representative Andrea Seastrand.

Others include Representatives Neil Abercrombie (D-HI), with a doctorate in sociology, and Brian Baird (D-VI) who holds a psychology Ph.D. Roscoe Barlett, Republican representative from Maryland, has an engineering Ph.D., while Representatives Vernon Ehlers (RMI) and John Olver (D-MA) hold theirs in nuclear physics and chemistry, respectively. Representative Glen Poshard (D-IL) holds a Ph.D. in educational administration.

In addition, several doctoral degree holders have high-level positions in the Clinton Administration. Secretary of State nominee Madeline Albright, Donna Shalala, Secretary of Health and Human Services, and Tony Lake, nominee for CIA Director, all hold Ph.D.s in political science.

\section{Hill Staff Speak Out on Science Funding at COSSA Annual Meeting}

Two Hill staff members specializing in science policy spoke at COSSA's annual meeting held last November. Their commentaries on the future funding of science research were not hopeful.

Skip Stiles, minority legislative director for the House Science Committee, predicted that research and development would be negatively affected in the wake of the balanced budget debate. Urging the research community to be "agile and politically connected," Stiles underscored the necessity of researchers taking an active role in defending their work.

He pointed to the research community's response to the last Congress's attempt to abolish the directorate of the Social, Behavioral, and Economic Science as a model of advocacy. Letters received by Congress made a difference in keeping the directorate and gave the research community the opportunity to educate Members about their disciplines. Stiles said that 1997 , since it is not an election year, would provide an ideal opportunity to educate Members further.

David Goldston, legislative director to Representative Sherwood Boehlert (R-NY), also spoke at the COSSA meeting. Boehlert is secondranking member on the Science Committee. Goldston was skeptical about the possibilities for bipartisan support for research funding, stating that, "common ground is where you find yourself when you don't have the votes to do what you want." Instead of cooperation, Goldston anticipates the continuation of the bad feelings present in the 104th Congress.

On the future of research funding, Goldston said that things were not "all that bright," though he added this was the effect of a tight budget, not because Members wish to attack scientific research. He warned that though the 104th spared many scientific funding initiatives, they may not be spared in the future.

Goldston urged the science community to rethink its priorities and begin to adapt them to present financial difficulties. He also urged researchers and educators to arrange for meetings with their Members, arguing that the science community could enhance Members support of their work.

Both Goldston and Stiles agreed that the National Endowment for the Humanities is also "on shaky ground," with Goldston characterizing NEH as a "very visible target [with] a vague, diverse, and not especially strong constituency."

APSA representative Sandy Maisel of Colby College attended the COSSA Annual Meeting, as did APSA Executive Director Catherine Rudder, a member of COSSA's Executive Board.

\section{Adapted from "COSSA Washington Update"}

\section{Future in Question for NEH and NEA}

A post-election report from the National Humanities Alliance, a Washington-based alliance supporting funding for the humanities, states that the National Endowment for the Humanities (NEH) and the National Endowment for the Arts (NEA) are presently "very vulnerable" in the hands of Washington policymakers, despite an increase in electoral support for educational funding.

According to the report issued in November 1996, House Speaker Newt Gingrich (R-GA) and Dick Armey (R-TX), House majority leader, will oppose budget appropri- 